\title{
*PENGARUH PERPUTARAN MODAL KERJA, PERPUTARAN KAS, DAN STRUKTUR MODAL TERHADAP PROFITABILITAS PERUSAHAAN PENYEDIA SPARE PART OTOMOTIF PERIODE 2007-2011
}

\author{
Yuliyati \\ Sunarto \\ Program Studi Akuntansi, Fakultas Ekonomi, \\ Universitas Sarjanawiyata Tamansiswa, Yogyakarta \\ Email : yuli_bintang@yahoo.com
}

\begin{abstract}
This research aimed to determine the effect of working capital turnover, cash turnover, and capital structure partially or simultaneously on the profitability of the companies of automotive spare parts 2007-2011. Profitability was measured by using return on investment (ROI).The data used was secondary data from the financial statements of the sample companies. Data analysis method used was the classic assumption of hypothesis testing. The statistical method used was multiple linear regression analysis. The sampling method used was purposive sampling. The dependent variable in this research was the profitability $(Y)$, the independent variables consisted of working capital turnover (X1), cash turnover (X2), and capital structure (X3).The results showed that the partial of working capital turnover has no any effect on return on investment (ROI), cash turnover affected the return on investment (ROI), capital structure affected the return on investment (ROI). Simultaneously, working capital turnover, cash turnover, and capital structure affected towards the return on investment (ROI) on the companies of automotive spare parts 2007-2011.
\end{abstract}

Keywords : working capital turnover, cash turnover, structure capital, and return on investment (ROI)

\section{PENDAHULUAN}

Kesuksesan perusahaan dapat dilihat dari kejelian dan efektifitas perusahaan dalam menggunakan aktivanya secara produktif. Modal kerja sebagai salah satu komponen penting dalam aktiva harus dikelola dan dimanfaatkan secara baik, efektif dan efisien sehingga mampu meningkatkan keuntungan atau profitabilitas bagi perusahaan. Keefektifan penggunaan modal kerja dapat diukur dengan rasio perputaran modal kerja. Keberhasilan suatu usaha agar dapat berjalan dengan baik yaitu dengan melihat dari kegiatan operasionalnya selama perusahaan tersebut berjalan dan dari kondisi keuangan perusahaan. Semakin tinggi perputaran kas berarti semakin cepat kembalinya kas masuk pada perusahaan. Perputaran kas yang tinggi menunjukan penggunaan kas yang tinggi pula. Tetapi apabila tingkat perputaran kas terlalu tinggi berarti jumlah kas yang tersedia semakin kecil. Perusahaan yang mempunyai proporsi utang jangka panjang dalam struktur modal semakin besar maka akan semakin besar pula risiko yang harus dihadapi oleh perusahaan, yaitu kemungkinan terjadinya ketidakmampuan perusahaan untuk membayar kembali utang jangka panjang beserta bunganya pada saat jatuh tempo. Dalam menentukan perimbangan antara besarnya utang dan jumlah sendiri yang tercermin dalam struktur modal perusahaan akan berpengaruh terhadap profitabilitas. Setiap perusahaan harus dapat memahami bagaimana menghasilkan profit, karena hal ini berkaitan dengan kemampuan perusahaan dan sumbersumber yang ada pada perusahaan seperti penjualan, kas, modal dan karyawan. Pengendalian terhadap perputaran modal kerja, perputaran kas, dan struktur modal tersebut diharapkan dapat meningkatkan profitabilitas perusahaan. Penelitian ini merupakan 
penelitian lanjutan dari penelitian sebelumnya. Beberapa penelitian yang telah dilakukan yang berkaitan dengan pengaruh perputaran modal kerja, perputaran kas, dan struktur modal terhadap profitabilitas menunjukan pengaruh dan signifikan. Akan tetapi ada beberapa peneliti yang mendapatkan hasil yang berbeda yaitu tidak ada pengaruh yang signifikan antara perputaran modal kerja dengan tingkat profitabilitas. Dari perbedaaan hasil yang diperoleh, penulis ingin menguji kembali bagaimana pengaruh perputaran modal kerja , perputaran kas, dan struktur modal terhadap profitabilitas dengan menjadikan perusahaan penyedia spare part otomotif sebagai objek penelitian dalam skripsi yang berjudul "Pengaruh Perputaran Modal Kerja, Perputaran Kas, dan Struktur Modal Terhadap Profitabilitas Perusahaan Penyedia Spare Part Otomotif Periode 2007-2011".

\section{Perputaran Modal Kerja}

Menurut Welas (2006), perputaran modal kerja (working capital turnover) merupakan rasio yang digunakan untuk mengukur berapa kali dana yang ditanamkan dalam modal kerja berputar dalam satu periode atau berapa penjualan yang dapat dicapai oleh setiap modal kerja yang digunakan. Munawir (2011) menyatakan bahwa untuk menghitung tingkat perputaran modal kerja (turnover capital) yaitu dengan membagi antara total penjualan dengan jumlah modal kerja ratarata. Rasio ini menunjukan hubungan antara modal kerja dengan penjualan dan menunjukan banyaknya penjualan yang dapat diperoleh perusahaan untuk tiap ukuran modal kerja. Menurut Azlina (2009) dalam jurnal "Pengaruh Tingkat Perputaran Modal Kerja, Struktur Modal dan Skala Perusahaan terhadap Profitabilitas" selama perusahaan terus beroperasi, modal kerja berputar terus menerus dalam perusahaan karena digunakan untuk membiayai operasi sehari-hari.

\section{Perputaran Kas}

Perputaran kas merupakan kemampuan kas dalam menghasilkan pendapatan sehingga dapat dilihat berapa kali uang kas berputar dalam satu periode tertentu. Menurut
Julkarnain (2011) dalam jurnal "Pengaruh Modal Kerja, Perputaran Modal Kerja, Perputaran Kas, dan Perputaran Piutang Terhadap Profitabilitas Pada Perusahaan Industri Barang Konsumsi Yang Terdaftar Di Bursa Efek Indonesia Tahun 2008-2011" menyatakan bahwa tingkat perputaran kas merupakan ukuran efisiensi penggunaan kas yang dilakukan oleh perusahaan, karena tingkat perputaran kas menggambarkan kemampuan perusahaan dalam menghasilkan laba yang berkaitan dengan tingkat pengembalian atas investasi. Sebaliknya apabila jumlah kas relatif kecil berarti perputaran kas tinggi sehingga perusahaan akan atau dapat berada dalam keadaan bangkrut. Menurut Kasmir (2011:141) Perputaran kas adalah perbandingan antara penjualan dengan jumlah kas rata-rata. Tingkat perputaran kas merupakan ukuran efisiensi penggunaan kas yang dilakukan oleh perusahaan.

\section{Struktur Modal}

Struktur modal dalam penelitian ini diukur dari Debt to Equity ratio (DER) dikarenakan DER mencerminkan besarnya proporsi antara total debt (total hutang) dan total shareholder's equity (total modal sendiri). Total debt merupakan total liabilities (baik utang jangka pendek maupun jangka panjang); sedangkan total shareholders'equity merupakan total modal sendiri (total modal saham yang disetor dan laba yang ditahan) yang dimiliki perusahaan. Rasio ini menunjukkan komposisi dari total hutang terhadap total ekuitas. Menurut Nurhasanah (2012) dalam jurnal "Pengaruh Struktur Modal Terhadap Profitabilitas Pada Perusahaan

menyatakan bahawa rasio yang umum digunakan untuk melihat pengaruh pinjaman dari kreditor baik digunakan sebagai tambahan modal maupun sumber dana untuk pembelian aktiva adalah rasio hutang yaitu dilihat dari struktur modal antara lain Debt to Equity Ratio (DER). Debt to Equity Ratio adalah variabel yang mendefinisikan seberapa banyak proporsi dari modal perusahaan yang sumber 
pendanaannya berasal dari pinjaman atau kredit.

\section{Profitabilitas}

Rasio profitabilitas merupakan aspek fundamental perusahaan, karena selain memberikan daya tarik yang besar bagi investor yang akan menanamkan dananya pada perusahaan juga sebagai alat ukur terhadap efektivitas dan effisiensi penggunaan semua sumber daya yang ada di dalam proses operasional perusahaan. Menurut Mamduh dan Halim (2003:85) rasio profitabilitas sebagai rasio yang mengukur kemampuan perusahaan menghasilkan keuntungan (profitabilitas) pada tingkat penjualan, aset, dan modal saham tertentu. Menurut Suryani, dkk (2012) dalam jurnal "Pengaruh Profitabilitas, Arus Kas Operasi, dan Arus Kas Bebas Terhadap Dividen Kas pada Perusahaan Manufaktur Terdaftar di Bursa Efek Indonesia Periode 2005-2009" menyatakan bahwa profitabilitas merupakan rasio yang digunakan untuk mengukur kemampuan perusahaan dalam menghasilkan laba (profit) pada tingkat penjualan, aset dan modal tertentu. Rasio profitabilitas sendiri dapat diukur dengan :

\section{Profit Margin}

Profit margin adalah rasio yang digunakan untuk menghitung sejauh mana kemampuan perusahaan menghasilkan laba bersih pada tingkat penjualan tertentu. Rasio ini bisa dilihat secara langsung pada analisis comman-size untuk laporan rugi-laba. Rasio ini bisa diinterpretasikan juga sebagai kemampuan perusahaan menekan biaya-biaya (ukuran efisiensi) di perusahaan pada periode tertentu. Rasio profit margin bisa dihitung sebagai berikut (Mamduh dan Halim, 2003:86)

$$
\text { Profit Margin }=\frac{\text { Laba Bersih }}{\text { Penjualan }}
$$

\section{ROE (Return on Equity)}

Rasio ini mengukur kemampuan perusahaan menghasilkan laba berdasarkan modal saham tertentu. Rasio ini merupakan ukuran profitabilitas dari sudut pandang pemegang saham. Rasio ROE bisa dihitung sebagai berikut (Mamduh dan Halim, 2003:87):

$$
\mathrm{ROE}=\frac{\text { Laba bersih }}{\text { Modalsaham }}
$$

\section{ROA (Return on Total Asset)}

ROA sering disebut juga sebagai ROI (Return On Investment), Rasio ini mengukur kemampuan perusahaan menghasilkan laba bersih berdasarkan tingkat asset tertentu. Rasio yang tinggi menunjukkan efisiensi manajemen asset, yang berarti efisiensi manajemen. Rasio ini bisa dihitung sebagai berikut (Mamduh dan Halim, 2003:86) :

$$
\text { ROI }=\frac{\text { bersih }}{\text { Total aset }}
$$

Berdasarkan pendapat tersebut maka dalam penelitian ini yang dipakai untuk menunjukkan rasio profitabilitas adalah ROI.

Dalam penelitian ini, hipotesis yang dirumuskan adalah :

$\mathrm{H}_{1}=$ Terdapat pengaruh perputaran modal kerja (working capital turnover), perputaran kas (cash turnover) dan struktur modal (capital structure) terhadap profitabilitas (ROI) pada perusahaan penyedia spare part otomotif periode 2007-2011.

$\mathrm{H}_{2}=$ Terdapat pengaruh perputaran modal kerja (working capital turnover) terhadap profitabilitas (ROI) pada perusahaan penyedia spare part otomotif periode 20072011.

$\mathrm{H}_{3}=$ Terdapat pengaruh perputaran kas (cash turnover) terhadap profitabilitas (ROI) pada perusahaan penyedia spare part otomotif periode 2007-2011.

$\mathrm{H}_{4}=$ Terdapat pengaruh struktur modal (capital structure) terhadap profitabilitas (ROI) pada perusahaan penyedia spare part otomotif periode 2007-2011.

Hipotesis di atas akan membuktikan apakah perputaran modal kerja (working capital turnover), perputaran kas (cash turnover), dan struktur modal (capital 
structure) baik secara sendir-sendiri atau bersama-sama berpengaruh terhadap profitabilitas (ROI) pada perusahaan penyedia spare part otomotif periode
2007-2011. Berdasarkan uraian tersebut dapat digambarkan kerangka pemikiran seperti gambar dibawah ini :

\section{Gambar 1}

\section{Kerangka Penelitian}

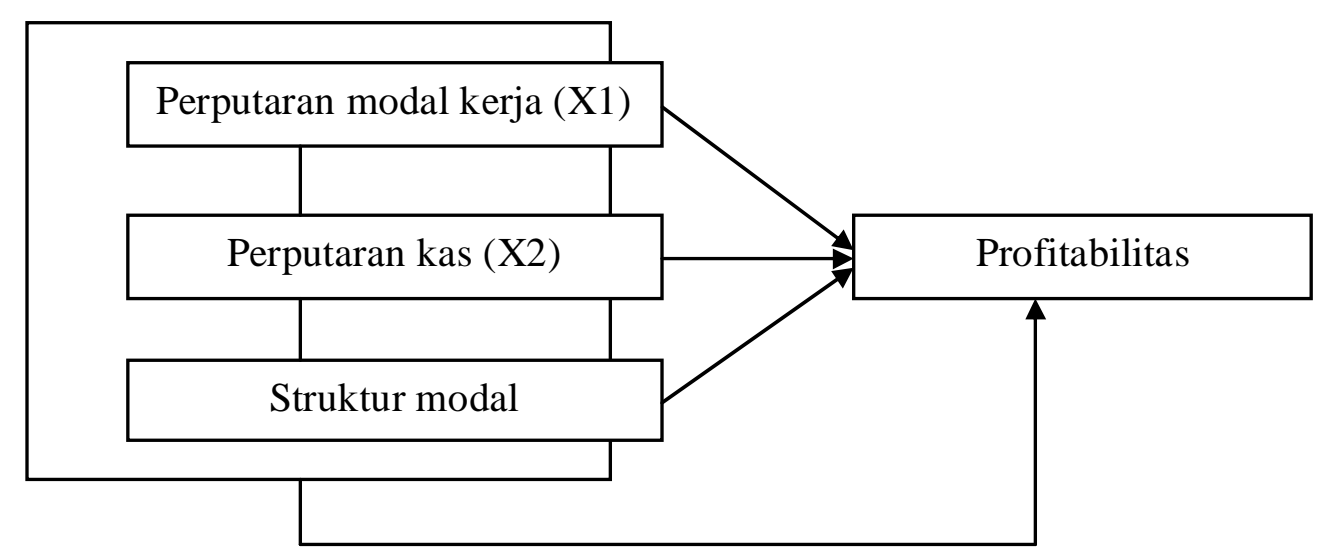

\section{METODOLOGI PENELITIAN}

Penelitian ini merupakan analisis deskriptif dengan pendekatan kuantitatif dengan tujuan untuk mengetahui pengaruh perputaran modal kerja, perputaran kas, dan struktur modal terhadap profitabilitas. Populasi yang digunakan dalam penelitian ini adalah seluruh perusahaan penyedia spare part otomotif yang terdaftar di BEI. Sampel adalah bagian dari jumlah dan karakteristik yang dimiliki oleh populasi tersebut (Sugiyono, 2013:120). Metode pengambilan sampel menggunakan purposive sampling yaitu sampel dipilih atas dasar kesesuaian karakteristik sampel dengan kriteria pemilihan sampel yang telah ditentukan. Jenis data yang digunakan dalam penelitian ini adalah data sekunder yaitu laporan keuangan. Data yang diperlukan adalah perputaran modal kerja, perputaran kas, dan struktur modal serta profitabilitas selama 5 tahun, yaitu tahun 2007 sampai dengan tahun 2011. Metode pengumpulan data yang diperoleh dari dokumen perusahaan yakni laporan keuangan tahunan yang telah dipublikasikan periode 2007 sampai 2011. Metode analisis data yang digunakan dalam penelitian ini adalah terdiri dari pengujian asumsi klasik dan pengujian hipotesis. Adapun pengujian asumsi klasik yang digunakan adalah uji normalitas, autokorelasi, multikolinearitas, dan heteroskedastisitas. Analisis yang digunakan untuk menganalisis permasalahan yaitu hubungan antara tingkat perputaran modal kerja, perputaran kas, dan struktur modal terhadap profitabilitas adalah analisis regresi linear berganda. Analisis digunakan untuk mengetahui pengaruh variabel bebas bersamasama terhadap variabel terikat. Adapun persamaan regresi linear berganda adalah :

$$
\mathrm{Y}=\mathrm{a}+\mathrm{b}_{1} \mathrm{X}_{1}+\mathrm{b}_{2} \mathrm{X}_{2}+\mathrm{b}_{3} \mathrm{X}_{3}+\mathrm{e}
$$

Keterangan :

Y

$\mathrm{X}_{1} \quad=$ Perputaran modal kerja

$\mathrm{X}_{2} \quad=$ Perputaran arus kas operasi

$\mathrm{X}_{3} \quad=$ Struktur modal (DER)

$\mathrm{a} \quad=$ Konstanta

$\mathrm{b}_{1}, \mathrm{~b}_{2}, \mathrm{~b}_{3}=$ Koefisien regresi

$\mathrm{e} \quad=$ Suku kesalahan, berdistribusi normal dengan rata-rata nol, untuk tujuan perhitungan, $\mathrm{e}$ diasumsikan nol.

Model regresi untuk menguji hipotesis dalam penelitian ini menggunakan uji $\mathrm{F}$ (simultan) 
dan uji $\mathrm{t}$ (parsial). Uji $\mathrm{F}$ digunakan untuk mengetahui apakah variabel independen secara bersama-sama atau simultan mempengaruhi variabel dependen. Uji $\mathrm{t}$ atau uji parsial digunakan untuk mengetahui pengaruh masing-masing variabel independen terhadap variabel dependen. Pengujian melalui uji $t$ dilakukan dengan menggunakan program SPSS.

Koefisien Determinasi

\section{HASIL DAN PEMBAHASAN \\ Hasil Uji Asumsi Klasik \\ a. Hasil Uji Normalitas}

Uji normalitas digunakan untuk mengetahui apakah model regresi berdistribusi normal atau tidak. Pengujian dilakukan dengan
Koefisien determinasi $\left(\mathrm{R}^{2}\right)$ pada intinya mengukur seberapa jauh kemampuan model dalam menerangkan variasi variabel dependen. Nilai $\mathrm{R}^{2}$ determinasi adalah di antara nol dan satu. Nilai $\mathrm{R}^{2}$ yang kecil, berarti kemampuan variabel-variabel independen dalam menjelaskan variasi variabel dependen amat terbatas. Nilai yang mendekati satu berarti : variabel- variabel independen memberikan hampir semua informasi yang dibutuhkan untuk memprediksi variasi variabel dependen.

menggunakan grafik yaitu normal p-p plot. Kurva normal p-p plot untuk pengujian normalitas regresi linear berganda antara perputaran modal kerja, perputaran kas, dan struktur modal terhadap profitabilitas dapat dilihat hasilnya sebagai berikut:

\section{Normal P-P Plot of Regression Standardized Residual}

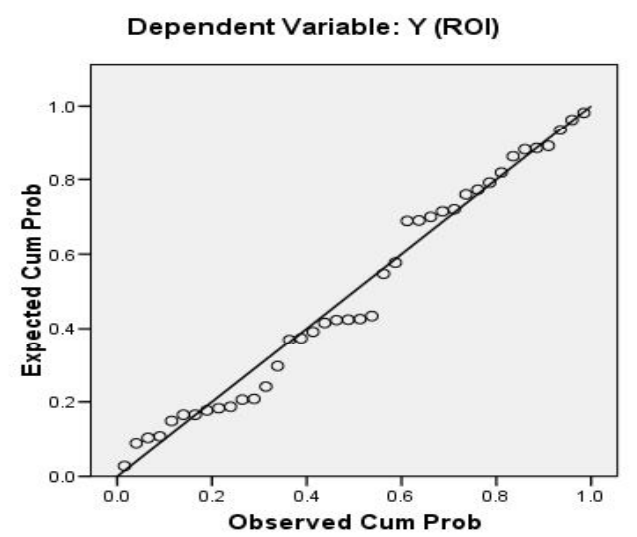

\section{Gambar 2 Grafik Normal Probabilty Plot}

Sumber : Data diolah, 2013

Hasil kurva normal probability plot memperlihatkan bahwa titik titik pada grafik berhimpit dan mengikuti garis diagonalnya,

\section{b. Uji Autokorelasi}

Analisis terhadap problem autokorelasi dilakukan dengan melihat nilai $\mathrm{dW}$ hitung. sehingga dapat disimpulkan model regresi berdistribusi normal.

Apabila nilai dW diantara -2 sampai +2 berarti tidak ada autokorelasi 
Tabel 1

Hasil Uji Autokorelasi

\begin{tabular}{ll}
\hline $\mathrm{dW}$ hitung & Keterangan \\
1,323 & Tidak terdapat gejala autokorelasi \\
\hline
\end{tabular}

Sumber: Data diolah, 2013

Berdasarkan Tabel 4.3 nilai dW sebesar 1,323

dapat disimpulkan bahwa model regresi tidak atau berada diantara -2 sampai +2 sehingga terjadi autokorelasi.

\section{c. Uji Multikolinearitas}

Analisis terhadap multikolinearitas dilakukan dengan melihat nilai variante inflation factor (VIF), jika nilai VIF yang diamati lebih besar dari 10 maka diduga terjadi problem multikolinearitas.

Tabel 2

Hasil Uji Multikolinearitas

\begin{tabular}{ccc}
\hline Variabel & VIF & Keterangan \\
\hline WCT & 1,027 & Tidak ada multikolinearitas \\
CT & 1,023 & Tidak ada multikolinearitas \\
DER & 1,034 & Tidak ada multikolinearitas \\
\hline
\end{tabular}

Sumber: Data diolah, 2013

Berdasarkan Tabel 2 menunjukan bahwa semua variabel independent (perputaran modal kerja, perputaran kas, dan struktur modal)

\section{d. Uji Heteroskedastisitas}

Analisis ada atau tidaknya problem heteroskedastisitas dilakukan dengan menggunakan scatterplot dimana sumbu $\mathrm{X}$ mempunyai nilai VIF $<10$, sehingga dapat disimpulkan bahwa model regresi tidak terjadi multikolinearitas.

adalah $\mathrm{Y}$ yang telah diprediksi dan sumbu $\mathrm{Y}$ adalah residual. Adapun hasil uji heteroskedastisitas dapat dilihat dalam grafik berikut ini:

Scatterplot

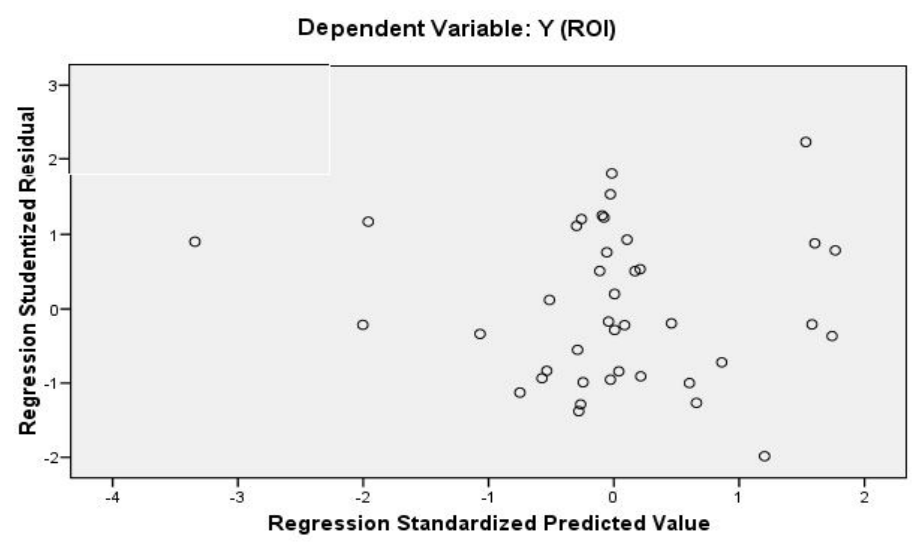

Gambar 3 Grafik Scatterplot

Sumber : Data diolah, 2013

Berdasarkan gambar 4.2 titik-titik pada scatterplot menyebar di kiri dan di kanan titik 0 pada sumbu X serta menyebar di bawah dan diatas titik 0 pada sumbu $\mathrm{Y}$, dan juga tidak membentuk pola tertentu, ini menunjukkan 
bahwa dalam model regresi tidak terdapat

\section{Hasil Uji hipotesis}

Berdasarkan uji asumsi klasik diatas terbukti bahwa model regresi yang diusulkan telah memenuhi keempat asumsi klasik yaitu mempunyai distribusi normal dan homogenitas serta terbebas dari gejala autokorelasi dan multikolinearitas. gejala heterokedastisitas.

\section{a. Hasil Uji F}

Uji $F$ digunakan untuk menganalisis pengaruh perputaran modal kerja, perputaran kas, dan struktur modal secara bersama-sama terhadap profitabilitas. Hasil uji F dapat dilihat pada tabel berikut ini:

Tabel 3

Hasil Uji F

\begin{tabular}{llrrrrr}
\hline Model & & $\begin{array}{c}\text { Sum of } \\
\text { Squares }\end{array}$ & \multicolumn{1}{c}{ df } & Mean Square & F & \multicolumn{1}{c}{ Sig. } \\
\hline 1 & Regression &, 027 & 3 &, 009 & 5,145 &, $005^{\mathrm{a}}$ \\
& Residual &, 063 & 36 &, 002 & & \\
& Total &, 091 & 29 & & & \\
\hline
\end{tabular}

Sumber: Data diolah, 2013

Uji $F$ yang dilakukan dengan cara membandingkan antara tingkat signifikansi dengan $\alpha(5 \%)$. Pada uji $F$ tingkat signifikansi sebesar 0,005 atau lebih kecil dari 0,05 sehingga terdapat pengaruh perputaran modal kerja, perputaran kas, dan struktur modal secara bersama-sama terhadap profitabiliatas.

\section{b. Hasil Uji t}

Uji $\mathrm{t}$ digunakan untuk menganalisis pengaruh perputaran modal kerja, perputaran kas, dan struktur modal secara sendiri-sendiri terhadap profitabilitas. Hasil uji $t$ dapat dilihat pada tabel berikut ini :

\section{Tabel 4}

Hasil Uji t

\begin{tabular}{|c|c|c|c|c|c|c|}
\hline \multirow{3}{*}{ Mod } & & \multirow{2}{*}{\multicolumn{2}{|c|}{$\begin{array}{l}\text { Unstandarized } \\
\text { Coefficients }\end{array}$}} & \multirow{3}{*}{$\begin{array}{c}\text { Standarized } \\
\text { Coefficients } \\
\text { Beta }\end{array}$} & \multirow{3}{*}{$t$} & \multirow{3}{*}{ Sig. } \\
\hline & & & & & & \\
\hline & & $\mathrm{B}$ & Std. Error & & & \\
\hline \multirow[t]{4}{*}{1} & (Constant) & ,063 & 011 & & 5,614 & ,000 \\
\hline & $\mathrm{X} 1$ (WCT) & ,000 & ,000 &,- 214 & -1.513 & ,139 \\
\hline & X2 (CT) & ,000 & ,000 & 303 & 2,146 & ,039 \\
\hline & X3 (DER) &,- 004 &, 001 &,- 383 & $-2,700$ & ,011 \\
\hline
\end{tabular}

Sumber: Data diolah, 2013

Uji $t$ digunakan untuk mengetahui pengaruh dari masing-masing variabel independennya terhadap variabel dependentnya. Uji t yang dilakukan dengan cara membandingkan antara tingkat signifikansi dengan $\alpha(5 \%)$.

1) Tingkat signifikansi untuk variabel perputaran modal kerja $\left(\mathrm{X}_{1}\right)$ sebesar 0,139 atau lebih besar dari 0,05 sehingga tidak terdapat pengaruh yang signifikan antara perputaran modal kerja terhadap profitabilitas.
2) Tingkat signifikansi untuk variabel perputaran kas $\left(\mathrm{X}_{2}\right)$ sebesar 0,039 atau lebih kecil dari 0,05 sehingga terdapat pengaruh yang signifikan antara perputaran kas terhadap profitabilitas.

3) Tingkat signifikansi untuk variabel struktur modal $\left(\mathrm{X}_{3}\right)$ sebesar 0,011 atau lebih kecil dari 0,05 sehingga terdapat pengaruh yang signifikan antara struktur modal terhadap profitabilitas.

Berdasarkan Tabel 4 persamaan regresi model 1 yang dihasilkan adalah:

$\mathrm{ROI}=0,063+0,000 \mathrm{WCT}+0,000 \mathrm{CT}$ 0,004DER 


\section{c. Hasil Koefisien determinasi}

Koefisien determinasi $\left(\mathrm{R}^{2}\right)$ pada intinya mengukur seberapa jauh kemampuan model dalam menerangkan variasi variabel dependen. Hasil koefisien determinasi dapat dilihat pada tabel berikut ini:

Tabel 5

Hasil Koefisien Determinasi

\begin{tabular}{llrrrr}
\hline Model & $\mathrm{R}$ & R Square & $\begin{array}{c}\text { Adjusted R } \\
\text { Square }\end{array}$ & $\begin{array}{c}\text { Std. Error of } \\
\text { the Estimate }\end{array}$ & Durbin-Watson \\
\hline 1 &, $548^{\mathrm{a}}$ &, 300 &, 242 &, 04195002 & 1,323 \\
\hline
\end{tabular}

Sumber: Data diolah, 2013

Hasil dari pengolahan data diperoleh nilai $\mathrm{R}^{2}$ sebesar 0,242 yang mempunyai arti bahwa variabel perputaran modal kerja, perputaran kas, dan struktur modal mempengaruhi profitabilitas sebesar $24,2 \%$, sedangkan $75,8 \%$ sisanya dipengaruhi oleh variabel-variabel lain diluar penelitian.

Hasil uji t menunjukkan bahwa tingkat signifikansi untuk variabel perputaran modal kerja $\left(\mathrm{X}_{1}\right)$ sebesar 0,139 atau lebih besar dari 0,05 sehingga tidak terdapat pengaruh antara perputaran modal kerja terhadap profitabilitas. Pengaruh perputaran modal kerja (working capital turnover) terhadap profitabilitas (ROI) pada perusahaan penyedia spare part otomotif periode 2007-2011 adalah positif. Efisiensi modal kerja dapat dinilai dengan menggunakan rasio antara total penjualan dengan jumlah modal kerja rata-rata yang sering disebut working capital turnover (perputaran modal kerja). Rasio ini menunjukkan hubungan antara modal kerja dengan penjualan yang dapat diperoleh perusahaan untuk tiap rupiah modal yang dikeluarkan.

Tingkat profitabilitas yang rendah bila dihubungkan dengan modal kerja dapat menunjukkan kemungkinan rendahnya volume penjualan dibanding dengan ongkos yang digunakan. Sehingga untuk menghindari itu, diharapkan adanya pengelolaan modal kerja yang tepat di dalam perusahaan. Perusahaan yang dikatakan memiliki tingkat profitabilitas tinggi berarti tinggi pula efisiensi penggunaan modal kerja yang digunakan perusahaan tersebut (Munawir, 2011). Namun hasil penelitian ini menunjukkan bahwa perputaran modal kerja tidak berpengaruh terhadap profitabilitas pada perusahaan penyedia spare part otomotif periode 2007-2011. Hal ini dapat terjadi karena pada beberapa perusahaan penyedia spare part otomotif mempunyai hutang lancar yang lebih besar dari aktiva lancar sehingga peningkatan perputaran kerja tidak selalu diikuti dengan kenaikan profitabilitas.

Hasil penelitian ini sejalan dengan Berhasak (2008) yang menyatakan bahwa tidak ada pengaruh signifikan antara manajemen modal kerja terhadap tingkat profitabilitas. Hasil uji t menunjukkan bahwa tingkat signifikansi untuk variabel perputaran kas $\left(\mathrm{X}_{2}\right)$ sebesar 0,039 atau lebih kecil dari 0,05 sehingga terdapat pengaruh antara perputaran kas terhadap profitabilitas. Variabel perputaran kas (cash turnover) berpengaruh positif terhadap profitabilitas (ROI) pada perusahaan penyedia spare part otomotif periode 2007-2011. Semakin tinggi perputaran kas maka profitabilitas juga cenderung tinggi, demikian pula sebaliknya semakin rendah perputaran kas maka profitabilitas juga cenderung rendah.

Pada penelitian ini terdapat pengaruh perputaran kas terhadap profitabilitas. Suatu perusahaan dapat diindikasikan berhasil apabila perputaran kas yang terjadi selama periode keuangan tertentu mengalami kenaikan. Perputaran kas yang terjadi selama periode tertentu dapat dijadikan sebagai acuan para investor dalam menambah investasi bagi perusahaan dalam pendanaan operasional dimasa yang akan datang. Perputaran kas merupakan perbandingan antara penjualan dengan jumlah kas rata-rata. Perputaran kas menunjukkan kemampuan kas dalam menghasilkan pendapatan sehingga dapat 
dilihat berapa kali uang kas berputar dalam satu periode tertentu. Semakin tinggi perputaran kas ini akan semakin baik. Karena ini berarti semakin tinggi efisiensi penggunaan kasnya dan keuntungan yang diperoleh akan semakin besar.

Perputaran kas masih berhubungan dengan penjualan yang tinggi pada perusahaan otomotif sehingga perputaran kas dapat digunakan untuk memprediksi keuntungan perusahaan. Hasil uji t juga menunjukkan bahwa tingkat signifikansi untuk variabel struktur modal $\left(\mathrm{X}_{3}\right)$ sebesar 0,011 atau lebih kecil dari 0,05 sehingga terdapat pengaruh antara struktur modal terhadap profitabilitas. Variabel struktur modal (capital structure) berpengaruh negatif terhadap profitabilitas (ROI) pada perusahaan penyedia spare part otomotif periode 2007-2011.

Pada penelitian ini struktur modal (capital structure) yang ditunjukkan dengan DER berpengaruh terhadap profitabilitas. Semakin tinggi nilai DER maka profitabilitas semakin rendah, demikian pula sebaliknya semakin rendah nilai DER maka profitabilitas semakin tinggi. Hasil penelitian ini sejalan dengan Nurhasanah (2012) menunjukkan bahwa struktur modal berpengaruh terhadap profitabilitas perusahaan. Struktur modal (DER) digunakan untuk mengukur seberapa banyak dana yang di supply oleh pemilik perusahaan dalam proporsinya dengan dana yang diperoleh dari kreditur perusahaan.

\section{KESIMPULAN}

Berdasarkan hasil analisis dan uji hipotesis yang telah dikemukakan, maka dapat ditarik kesimpulan sebagai berikut :

1. Perputaran modal kerja, perputaran kas, dan struktur modal berpengaruh secara simultan terhadap Return On Investment (ROI) pada perusahaan penyedia spare part otomotif periode 2007-2011.

2. Perputaran modal kerja tidak berpengaruh secara parsial terhadap Return On Investment (ROI) pada perusahaan penyedia spare part otomotif periode 2007 2011.
3. Perputaran kas berpengaruh secara parsial terhadap Return On Investment (ROI) pada perusahaan penyedia spare part otomotif periode 2007-2011.

4. Struktur modal berpengaruh secara parsial terhadap Return On Investment (ROI) pada perusahaan penyedia spare part otomotif periode 2007-2011.

Berdasarkan hasil penelitian dan kesimpulan diatas, ada beberapa hal yang dapat disarankan penulis ;

1. Bagi peneliti berikutnya, disarankan agar mencari variabel lain yang berpengaruh terhadap profitabilitas.

2. Bagi investor, disarankan untuk memperhatikan struktur modal dan perputaran kas dalam berinvestasi supaya memperoleh keuntungan yang diinginkan.

3. Bagi perusahaan, disarankan untuk berhati-hati dalam menggunakan struktur modal dan perputaran kas karena akan mempengaruhi profitabilitas.

\section{DAFTAR PUSTAKA}

Abdul Halim, 1993. Dasar-Dasar Pembelanjaan Perusahaan. Edisi Kedua. Yogyakarta: BPFE.

Arista, 2012. Analisis Faktor-Faktor yang Mempengaruhi Return Saham (Kasus pada Perusahaan Manufaktur yang Go Public di BEI Periode Tahun 20052009). Jurnal Ilmu Manajemen dan Akuntansi Terapan, Vol 3 (1).

Azlina, N. 2009. Pengaruh Tingkat Perputaran Modal kerja, Struktur Modal dan Skala Perusahaan terhadap Profitabilitas. Jurnal Pekbis Voll (2).

Berhasak, E. 2008. Efek Modal Kerja Terhadap Profitabilitas PerusahaanPerusahaan di Industri Manufaktur di Indonesia pada Tahun 2007. Tesis Program Studi Magister Manajemen, Universitas Indonesia, Jakarta.

Brigham. E. F. \& Weston J. F, 2001, Manajemen Keuangan, Alih Bahasa: Dodo Suharto dan Herman Wibowo. Edisi Kedelapan, Buku Kedua, Erlangga, Jakarta.

Damarathi P, 2008. Pengaruh Manajemen Modal Kerja terhadap Profitabilitas 
Perusahaan Go Public Sektor Manufaktur di Indonesia Tahun 2002 2006. Skripsi Fakultas Ekonomi, Universitas Indonesia, Jakarta.

Harjanti, W. 2009. Analisa Perputaran Piutang terhadap Modal Kerja pada Perusahaan Jasa PT. ABJ Surabaya. Jurnal Media Mhardhika Vol. 8 (2).

Hayati, N dan Riani, C. 2011. Pengaruh Arus Kas terhadap Likuiditas pada Perusahaan Telekomunikasi yang Terdaftar di BEI. Jurnal Spread, Vol.1(1)

IAI. 2007 . Standar Akuntansi Keuangan . Edisi 2007. Jakarta: Penerbit Salemba Empat

Julkarnain, 2011. Pengaruh Modal Kerja, Perputaran Modal Kerja, Perputaran Kas, dan Perputaran Piutang Terhadap Profitabilitas Pada Perusahaan Industri Barang Konsumsi Yang Terdaftar Di BEI Tahun 2008-2011.

Mamduh, M.H. dan Halim, A. 2003. Analisa Laporan Keuangan. Edisi revisi. Yogyakarta: Penerbit UPP AMP YKPN.

Mardiasmo, 1997. Akuntansi Keuangan Dasar. Yogyakarta: BPFE

Martono dan Harjito, 2005, Manajemen Keuangan. Edisi pertama, cetakan keempat, Jakarta: Penerbit Jala Sutia.

Miswanto, 2012. Kebijakan dalam Penentuan dan Pendanaan Modal Kerja Perusahaan. Jurnal Economia, Vol. $8(2)$

Munawir. 2011. Analisa Laporan Keuangan.Yogyakarta: Liberty.

Nurhasanah, 2012. Pengaruh Struktur Modal Terhadap Profitabilitas Pada Perusahaan Manufaktur Yang Terdaftar Di BEI. Jurnal Ilmiah Vol.IV (3) 2012

Ogolmagai, N. 2013. Leverage Pengaruhnya terhadap Nilai Perusahaan pada Industri Manufaktur yang Go Public di Indonesia. Jurnal EMBA Vol. 11 (3).

Panigoro, W. 2010. Analisis Profitabilitas Perusahaan PT. Cahaya Nusa Sulutarindo. Jurnal Economic Resources, Vol.11 (31).
Pramono, J dan Khatimah, H. 2007. Pengaruh Waktu dan Jenis Industri pada Strategi Manajemen Modal Kerja: Survey pada Industri Otomotif, Garment dan Makanan di Bursa Efek Jakarta. Jurnal Optimal Vol. 1 (1).

Qodriyah, R. 2012. Laba atau Arus Kas sebagai Parametek Kinerja Perusahaan Berdasarkan Siklus Hidup Perusahaan (Studi Relevansi Nilai). Jurnal Akuntansi dan Ekonomi Bisnis, Vol.1, (1).

Riyanto, B. 2004. Dasar-dasar Pembelanjaan Perusahaan. Yogyakarta : Liberty.

Santoso, S. 2001. SPSS: Statistik Parametrik. Cetakan kedua, Jakarta: Penerbit PT Elex Media Komputindo Kelompok Gramedia.

Sugiyono. 2013. Metode Penelitian Kombinasi. Bandung Alfabeta.

Sunrowiyati, 2009. Analisis Variabel-Variabel Keuangan yang Memengaruhi Struktur Modal Perusahaan Manufaktur yang Go Public di Bursa Efek Jakarta. Jurnal Kompilasi Ilmu Ekonomi Vol.1 (1).

Supriadi, Y dan Puspitasari, R. 2012. Pengaruh Modal Kerja Terhadap Penjualan dan Profitabilitas Perusahaan. Jurnal Ilmiah Kesatuan Vol. 14.(1).

Suryani E, Arfan M dan Djalil MA. 2012. Pengaruh Profitabilitas, Arus Kas Operasi, dan Arus Kas Bebas Terhadap Dividen Kas pada Perusahaan Manufaktur Terdaftar di Bursa Efek Indonesia Periode 2005 2009. Jurnal Akuntansi Vol 1. (1).

Sutarti. 2012. Penyajian Laporan Arus Kas menurut PSAK 2 Guna Mendukung Pengambilan Keputusan Investasi pada PT Pan Brothers Tbk. Jurnal Ilmiah Kesatuan Vol. 14 (1).

Welas. 2006. Analisis Kinerja Keuangan dengan Pendekatan Sistem Du Pont (Studi Empirik pada Perusahaan Rokok yang Sudah Go Public Periode Tahun 2000 - 2004). Jurnal Akuntansi Keuangan Vol.1(1) 